\title{
A POLICY PERSPECTIVE ON COCONUT PROCESSING IN THE SOUTH PACIFIC ISLANDS ${ }^{1}$
}

\author{
Dan M. Etherington ${ }^{2}$
}

\begin{abstract}
For many island nations of the South Pacific the coconut palm is the most important smallholder tree crop. Most attempts to introduce processing; beyond the copra stage have failed. At the same time there is a declining trend in copra prices. Unlike most other major coconut producing countries (Philippines, India, Indonesia, Sri Lanka, and Thailand), the South Pacific nations do not have significant expanding domestic urban markets. As a result they must look to alternative export markets and direct output to higher income, non-traditional market niches.

This paper, part of an on-going research project, presents arguments in favour of an export 'demand-pull' strategy for the coconut industry based on a re-examination of the coconut as a total resource rather than only as a source of a raw vegetable oil. The effective use of this resource requires that the fruit be processed as a mature fresh nut and that all parts of the nut are used. The strategy implies a switch in research priorities, away from plant breeding and disease control towards processing, domestic and international shipping, energy policies and market development. Improved markets would in turn give renewed impetus to the continuation of the excellent plant breeding work that has already been done.
\end{abstract}

\section{AN OVERVIEW}

Coconut palms (Cocos nucifera) and their large fruit are ubiquitous in the islands of the South Pacific. The fruiting of this palm is so regular and its products so numerous that many refer to it as the "tree of life". The nuts form an important part of the local diet as a drink, fresh food and as an ingredient in cooking. For many Pacific Island communities, the dried flesh of the mature nut ('copra') is their most important export commodity. For some it is their only trade good. Prices of copra in recent years have fluctuated dramatically, from a nonn of about US\$300/tonne (CIF Rotterdam) to over $\$ 800 /$ tonne in 1984 to only $\$ 150 /$ tonne in mid-1986 but recovering somewhat during 1987. While coconut production is a relatively easy occupation because the palms are hardy, live long (over 60 years) and produce all the year round, the processing of the fresh flesh to produce copra is a dirty and arduous task. ${ }^{3}$ For the people of the South Pacific to continue to do this work the retums to their labour are critical. In an attempt to increase the returns to growers and the value added to the nations, Island govemments have sought to undertake domestic copra milling for the resultant coconut oil and livestock feed-cake. Few such undertakings have been successful (Wall 1986).

This paper starts by setting a number of policy goals for the industry. It then reviews the process of structural transformation and its significance for the islands. This is followed by a brief

\footnotetext{
${ }^{1}$ Many people who provided useful comments on an earlier 'in house' discussion paper have stimulated me to revise it for wider circulation. I am particularly grateful to David Hagen of Hawaii for his major input on many technical and engineering issues faced by the project. I remain responsible for all shortcomings.

2 Economics Department, Research School of Pacific Studies, Australian National University Canberra, ACT 2601.

${ }^{3}$ Raw, or green, copra has a moisture content of $50 \%$. This has to be reduced to less than $7 \%$ before the copra can be traded, Child (197 4) and Banzon et al (1982) describe how copra is made and how it is further processed to produce edible coconut oil. Brookfield (1985) gives figures ftom Fiji on the typical labour requirements for producing copra.
} 
sketch of the small size and remoteness of the islands and their dependency on foreign trade and aid. The cunent situation of the coconut industry is then outlined. The policy perspective is developed and then applied to development strategies for the industry. The paper ends with specific recommendations for the direction of research and poses a lot of questions which need to be answered.

\subsection{Policy Goals}

I accept Stewart and Streeten's 1976 definition of a strategy as including both the objectives and the set of policies designed to achieve those objectives. Here, with a "Logical Framework" (or "Logframe") structure in mind, the top-level goals are to:

1. Raise the economic and social welfare of Pacific Island nations by improving the utilization of and the value added to existing resources.

2. Stem the migration from outer islands and emigration from the islands nations.

3. Improve national self-sufficiency in food and fuel, and diversify their inclustries and exports.

4. Improve intra-national communications and encourage the social cohesion of community organizations.

5. Impart technical skills and retain them within the islands.

That these lofty ideals are the overall goals of policies focusing on the coconut sector of the island economies is due to the widespread presence of the palms, the characteristics of the nut itself and modern technological developments.

I also accept the challenge of Chambers (1978) for social scientists to understand and be involved in research and development $(\mathrm{R} \& \mathrm{D})$ as it could affect rural people rather than simply analyze events after they have taken place (see also Longworth 1987). Chambers' agencia requires that we pay specific attention to find ing out what scientists and technologists are currently working on; to leaming from rural people; to ensuring environmental specificity and to having a 'future-orientation' (Chambers 1978 p 5). Pertinent examples of new technologies for small scale, remote, rural processing plants would include the use of micro-processors (reducing managerial requirements), co-generation power units, and the use of renewable-energy resources in the face of medium term projections that indicate a tightening of world oil supplies. Such a future orientation needs to keep in mind not merely the productivity of a systern but its stability, sustainability and equitability (Conway 1985). One of the intentions of this paper is to establish research priotities for agriculture - although they are not derived from a formal model (Davis and Ryan 1987, Davis et al 1987).

\section{THE PROCESS OF STRUCTURAL TRANSFORMATION}

Historically, the process of economic development shows a steady decline in the share of agriculture in the national income, and in the proportion of the labour force in the agricultural sector. Eventually the actual numbers employed in agriculture decline. The basic reasons for this process of structural transformation are well understood (Chenery 1960, Kuznets 1957, Johnston \& Mellor 1960, Johnston \& Kilby 1975, Johnson 1987). The transformation from an agrarian to an industrial/service society is a complex process. This is evident from the economic and social difficulties being faced within and among any cross-section of societies. Nevertheless the overall trends of structural transformation show a consistent patern for good reasons. In general tenns, the 
agricultural sector produces many of the basic necessities of life: without food we die. But necessities have income elasticities of demand of less than one. Thus as real incomes rise, the demand for the sum of all farm products grows more slowly than does the demand for all other goods and services. Not only arc income elasticities of demand for food, less than one but they decline as incomes rise. The general weakness of the domestic demand growth for agricultural products is well demonstrated by equation (1).

$$
\mathbf{d}=\mathbf{p}+\mathbf{n g}
$$

Here the ' $\mathbf{d}$ ' is the rate of growth of demand for agricultural products; 'p' is the rate of growth of population; ' $\mathbf{n}$ ' the income elasticity of demand and ' $\mathrm{g}$ ' the rate of gyowth of ver caoita incomes. The lower the ' $\mathbf{n}$ ' for any income growth rate, the lower the rate of growth in domestic demand.

On the supply side, if agricultural productivity increases at about the same rate as other sectors of the economy but has an income elasticity of less than one, 'agricultures fate is to shrink' (Johnson 1987. p.3). Australia and New Zealand are often cited as evidence that this fate is not restricted to a closed economy but also affects small countries with an absolute advantage in agricultural production.

While the general scenario for the agricultural sector is for a steady decline in its relative importance, in a closed economy the relative fortunes of industries within the sector will vary according to the product specific income elasticities of demand and the rates at which supply shifts (productivity improvements) take place. At the one extreme there are the starchy staples of rice, wheat, maize and root crops such as potato, sweet potato, and cassava which forin the bulk of human food. Income elasticities of demand for such commodities tend to be very low. The proportion of food expenditures spent directly on starchy staples declines as incomes increase (Bennet 1954). ${ }^{4}$ At the other extreme, agriculture produces luxuries such as caviar, spices, essential oils and cut flowers. Between these extremes there is a wide range of agricultural products some of whose income elasticities of demand are close to one.

Strategic planning for 'luxury' agricultural products can be safely ignored in a closed economy but within small open economies such products are likely to be crucial in raising rural and national incomes. They should form a key component of the agricultural strategies of the 'micro' island nations of the South Pacific. This argument will be developed following an outfine of the setting. ${ }^{5}$

\section{THE SETTING}

The South Pacific island nations are among the most marginal but possibly the most studied in the world. They are 'marginal' in many senses: small in physical size and in numbers of people, on the periphery of trade and communication routes, their very remoteness makes them little more than an irritant to those concemed with the 'development' of nations. Goodwill towards themby high income countries is mixed with some sense of honelessness and helplessness as to what can be done. For world and regional powers, only their strategic location gives them some significance.

\footnotetext{
${ }^{4}$ Indirect expenditures are not nearly as income inelastic because in many countries the animals that provide the protein in human diets are fed with grain.

${ }^{5}$ Such a brief sketch does great injustice to the enormous diversity found among the islands and their peoples, but to do justice at this point would divert the central argument. The South Pacific Agricultural Survey, edited by Ward et al (1980) provides an excellent country by country review of agriculture in the islands. The Islands/Australia Working Paper Series of the National Centre for Development Studies, Australian National University covers many.
} 
Table 1. Demographic and income indicators South Pacific Island Nations 1983

\begin{tabular}{|c|c|c|c|c|c|c|}
\hline \multirow[t]{2}{*}{ Country } & $\begin{array}{c}\text { Population } \\
\text { Total }\end{array}$ & $\begin{array}{l}\text { Growth } \\
\text { Rate }\end{array}$ & $\begin{array}{l}\text { Density } \\
\text { (people } \\
\text { per km²) }\end{array}$ & $\begin{array}{l}\mathrm{Pr} / \mathrm{Pt} \\
\text { Ratio } \\
1980\end{array}$ & GNP* & $\begin{array}{l}\text { GNP per } \\
\text { Capita* }\end{array}$ \\
\hline & $\left({ }^{\prime} 000\right)$ & $\% \mathrm{a}$ & No. & $\% b$ & \$USm & \$US \\
\hline Cook Islands & 22 & & 92 & & 20 & 909 \\
\hline Fiji & 670 & 1.8 & 37 & 61 & 1,190 & 1,776 \\
\hline French Polynesia & 154 & & 47 & & 1,260 & 8,182 \\
\hline Kiribati & 61 & & 88 & & 30 & 492 \\
\hline Nauru & 3 & & 143 & & 79 & 23,333 \\
\hline New Caledonia & 146 & & 8 & & 1,140 & 7,808 \\
\hline Nieu & 3 & & 12 & & 3 & 1,000 \\
\hline Papua New Guinea & 3,190 & 2.3 & 7 & 88 & 2,510 & 787 \\
\hline Solomon Islands & 254 & 3.5 & 9 & 90 & 160 & 630 \\
\hline Tokelau & 2 & & 200 & & 1 & 500 \\
\hline Tonga & 104 & 0.9 & 149 & 68 & 80 & 769 \\
\hline Tuvalu & 8 & & 308 & & 4 & 500 \\
\hline Vanuatu & 127 & 2.8 & 11 & 82 & 80 & 630 \\
\hline Western Samoa & 161 & 0.6 & 55 & 77 & 119 & 729 \\
\hline TOTAL & 4,905 & & 9 & & 6,667 & 1,359 \\
\hline
\end{tabular}

Sources: Statistical Annex Pacific Economic Bulletin July 1986.

${ }^{a}$ Lucas \& McMurray (1 986) and McMurray (1 986)

${ }^{\mathrm{b}} \mathrm{Pr} / \mathrm{Pt}$ is the ratio of Rural to Total population. These are 1 the urban ratios given in Ahlburg (1986) Table 11, P. 28

* Although the figures for GNP are given here, it is the opinion of many that they are of little use and very misleading.

Their problems are very real. The populations of most of these nation states are barely the size of a small 'town' or 'city' (2,000 -300,000; see Table 1 which also shows the variation in population density and growth rates). But this 'town, is divided by 'streets' of water hundreds of miles wide with the people of each 'suburb' often speaking a different language. Commuting is measured in terms of hours or days and can only occur at the random and occasional appearance of a 'bus' (boat) at one of the few 'stops' (wharfs). Aircraft have greatly improved commucations but movement is still either slow and/or expensive. Journeys are, therefore not made lightly and 'commuting' tends to be measured in days and weeks rather than hours. There are strong centripetal forces taking the younger, male, best educated and most adventurous to the central town or centrifugal. forces encouraging emigration from the islands to larger, higher income nations (particularly from Polynesian countries) (Lucas \& McMurray 1986). These 'brain-drain' movements can have serious implications for the bereft communities in terms of future innovation, leadership and community solidary (Connel 1980, 1983).

The reverse side of the coin of the relative remoteness of the Pacific Islands is the resourcefulness of the people. Of necessity, the people of the South Pacific have had to be highly self-sufficient in their lifestyles. Family and/or group loyalties tend to be very strong. The phrase "subsistence affluence" was coined to describe the livelihoods of many of these peoples who lived well by international standards, producing what they consurne and consurning what they produce (Fisk 1971 and 1986). ${ }^{6}$ But increasingly this self-sufficiency is being eroded by trade-dependency ${ }^{6}$ Such self-sufficient societies have provided economists with a rich and fruitful ground for building economic
models of various types of subsistence farming situations and the transition between such farms and 
and aiddependency (Fisk 1981). Such dependency is not necessarily bad, but in primary product trade, the producers of unprocessed raw materials are subjected to particularly wide fluctuations in prices and to fickle markets. In addition, there are concems on the import side of the trade equation.

\subsection{Trade-dependency}

\subsubsection{Export trade}

Copra enters the world fats and oils market as just one of a large number of sources of vegetable oil. Within these oils a major distinction can be drawn between annual oilseed crops (soybeans, sunflower, cottonseed, groundnut and rapeseed) and perennials (notably, oil palm, coconut and olive). The steady increases in world production since the 1960s of rapeseed oil (6.8\% per annum, mainly in Westem Europe, China, India and Canada), soybean (about $6.2 \%$ per annum, mainly in the United States, Brazil and Argentina) and the rapid increase in palm oil production in Asia (with Malaysia's output increasing at about 19\% per annum since 1961) has had an overall depressing effect on international oilseed prices since demand in importing countries has not increased as rapidly (see World Bank 814/86).

Within this large and complex market the South Pacific islands are very minor actors: none of thern feature among the 23 countries with annual oilseed production exceeding 100,000 tonnes (Moll 1987, P.52). The pertinent conclusion to, draw is that these island nations are price takers faced with perfectly elastic markets at current prices for any particular quality of product. Even within the coconut 'world' the Islands are not very significant (Table 2).

Nevertheless, trade in coconut products is extremely important for these individual countries in terms of the share of exports accounted for by these products. Vanuatu is an extreme example : copra exports accounted for about 68\% of export eamings in 1985 (a relatively "normal" year).

The problem with such dependency is that instability in the price of copra has been particularly severe over the last decade and a half Figure 1 shows the fluctuations in real prices at the destination, or consumer, markets (CIF). Normally one would expect the difference between the real CIF and FOB to be strongly related to the CIF price and to have a positive intercept - indicating a relatively stable 'marketing margin' and greater instability in FOB prices. However, there is an unexpected negative intercept, implying that the instability in FOB prices is less than that of CIF prices! ${ }^{7}$ The actual difference is slight with the coefficient of variation for FOB prices being 0.30 compared to 0.31 for CIF prices.

commercial agriculture. These include the works Fisk, Nakijima, Nicholls, Sachlins, Schults, Shand, and Stent. Stent 1984 gives a useful review of this literature.

7 These results are based on the statistic reported in World Bank 814/86 Vol II Annex Tables 28 an 32. Regressing $\mathrm{D}=\mathrm{CIF}-\mathrm{FOB}$ on CIF (in real terms) and time (1953-85) in the form $\mathrm{D}=\mathrm{A}+\mathrm{bCIF}+\mathrm{ct}+\mathrm{u}$ we get:

$\begin{array}{lcc}\text { Parameter } & \text { Coefficient } & \text { T-ratio } \\ \text { A } & -99.97 & 2.11 \\ \text { b } & 0.275 & 5.59 \\ \text { c } & 2.203 & 1.76\end{array}$

Corrected R2 $=0.55$

The explanation for the unexpected negative intercept may lie in the pooled nature of the statistics and may not hold for individual countries. 
Table 2. Population and Coconut statistics for Selected Countries 1985

\begin{tabular}{|c|c|c|c|c|c|c|c|}
\hline \multirow[b]{2}{*}{ Country } & \multirow{2}{*}{$\begin{array}{l}\text { Popula- } \\
\text { tion mid- } \\
1985\end{array}$} & \multicolumn{2}{|c|}{ Coconut production } & \multirow{2}{*}{$\begin{array}{l}\text { Coconut } \\
\text { s } \\
\text { Per } \\
\text { Capita }\end{array}$} & \multirow{2}{*}{$\begin{array}{c}\text { Estimated } \\
\text { Coconut } \\
\text { Area }\end{array}$} & \multirow{2}{*}{$\begin{array}{l}\text { Eeport } \\
\text { Value of } \\
\text { Coconut } \\
\text { Products }\end{array}$} & \multirow{2}{*}{$\begin{array}{l}\text { Ccoonut } \\
\text { Exp as \% } \\
\text { Total } \\
\text { Export }\end{array}$} \\
\hline & & $\begin{array}{c}\text { Nut } \\
\text { Equivalent }\end{array}$ & $\begin{array}{c}\text { Copra } \\
\text { Equivalen } \\
t\end{array}$ & & & & \\
\hline & (millions) & (millions) & $\begin{array}{r}(000 \\
\text { tons) }\end{array}$ & Nuts & (000 ha) & $\begin{array}{r}\text { M US\$ } \\
\text { FOB }\end{array}$ & $\%$ \\
\hline APCC*COUNTRIES & $1,096.55$ & 33,759 & & 30.70 & 8,986 & 1003.26 & \\
\hline $\begin{array}{l}\text { Indiaa } \\
\text { Of which }\end{array}$ & 792.92 & 6,887 & $\begin{array}{l}6,339 \\
1,028\end{array}$ & 8.69 & 1,193 & 24.36 & .28 \\
\hline Kerala & 25.5 & 3,395 & & 133 & 689 & & \\
\hline Tamil Nadu & 48.4 & 1,627 & 507 & 33 & 153 & & \\
\hline Karnataka & 37.1 & 1,011 & 243 & 27 & 194 & & \\
\hline Indonesia & 165.15 & 9,050 & 151 & 54.80 & 3,060 & 149.55 & .80 \\
\hline Malaysia & 15.28 & 1,165 & 1,810 & 76.24 & 315 & 51.43 & .38 \\
\hline Papua New Guinea & 3.26 & 1,255 & 221 & 384.97 & 241 & 58.30 & 6.34 \\
\hline Philippines & 53.35 & 10,749 & 250 & 201.48 & 3,275 & 551.95 & 12.00 \\
\hline Solomon Islands & .27 & 209 & 2,051 & 782.77 & 63 & 14.56 & 22.60 \\
\hline Sri Lanka & 15.84 & 2,958 & 46 & 186.74 & 419 & 119.76 & 9.00 \\
\hline Thailand & 50.20 & 706 & 601 & 14.06 & 281 & 9.37 & .13 \\
\hline Vanuatu & .13 & 402 & 200 & $3,140.63$ & 69 & 12.35 & 68.00 \\
\hline Western Samoa & .16 & 248 & 56 & $1,559.75$ & 42 & 7.35 & 33.39 \\
\hline F.S. Micronesia & $\mathrm{n} / \mathrm{a}$ & 60 & 50 & n/a & 14 & 1.40 & $\mathrm{n} / \mathrm{a}$ \\
\hline Palau & $\mathrm{n} / \mathrm{a}$ & 70 & $\begin{array}{l}12 \\
14\end{array}$ & $\mathrm{n} / \mathrm{a}$ & 14 & 2.89 & $\mathrm{n} / \mathrm{a}$ \\
\hline OTHER PACIFIC (1983) & & 668 & 134 & $\mathrm{n} / \mathrm{a}$ & & & \\
\hline Fiji & .67 & 263 & 53 & 392.54 & & & \\
\hline Tonga & .11 & 69 & 14 & 627.27 & & & \\
\hline Others & $\mathrm{n} / \mathrm{a}$ & 336 & 67 & $\mathrm{n} / \mathrm{a}$ & & & \\
\hline OTHER ASIA 1983 & & 804 & 161 & & & & \\
\hline AFRICA 1983 & & 1,943 & 389 & & & & \\
\hline AMERICAS 1983 & & 2,524 & 505 & & & & \\
\hline TOTAL & & 39,698 & 7,528 & & & & \\
\hline
\end{tabular}

Source : Asia and Pacific Coconut Cornmunity $(=*$ APCC), Coconut Statitical Yearbook 1985 Jakarta, November 1986. Various tables. To eive average figures for the whole of India is misleading since nearly 90 per cent of production cccurs in just three of India's 31 States: Kerala, Tamil Nadu and Kamataka. The State population figures given here are for the 1981 census so the per capita production figures are only a rough guide. 


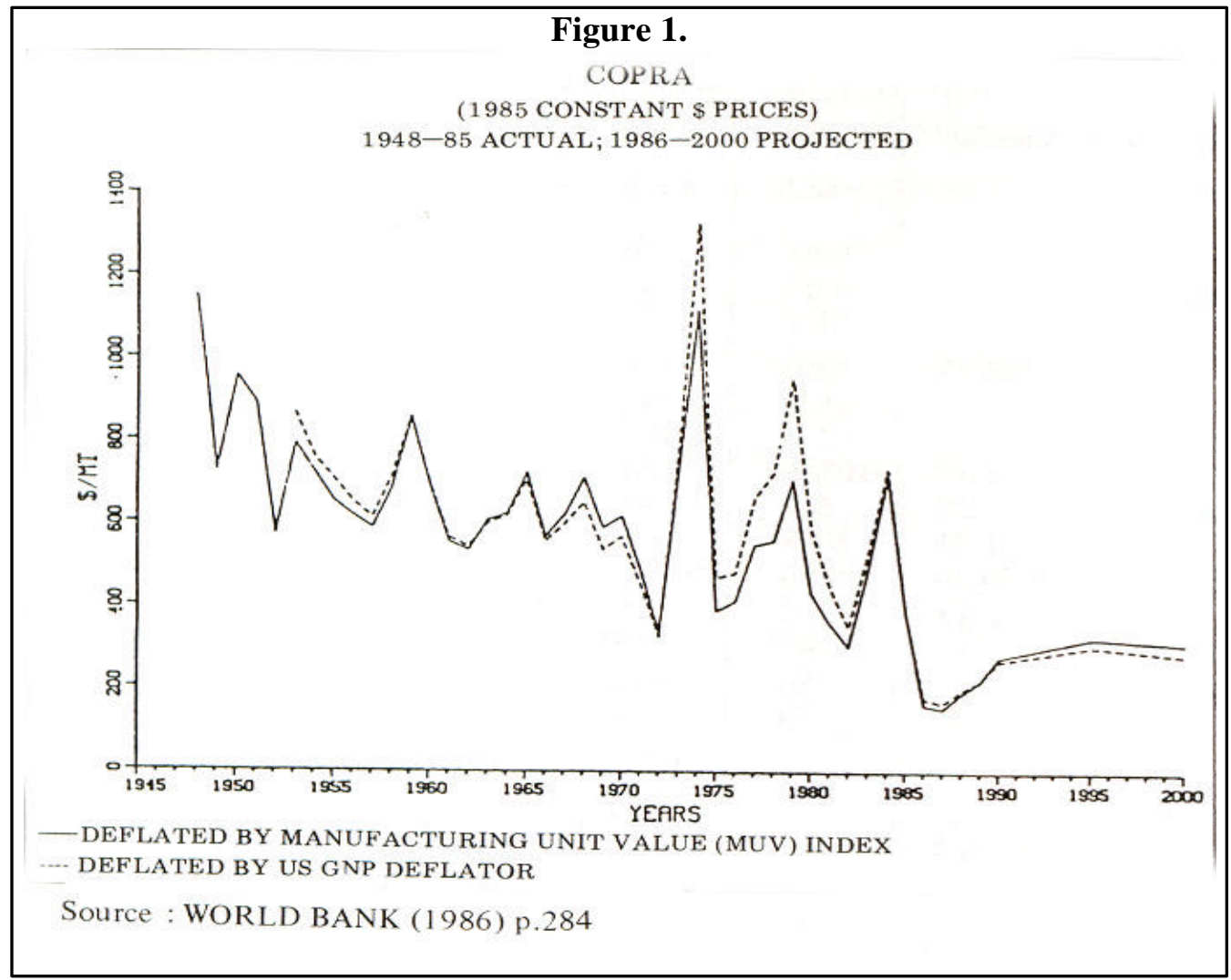

PRICE MOVEMENTS OF COPRA AND COCONUT OIL 1950-1986

Such price instability is caused by shifts in both the supply of and the demand for copra. The supply shifts occur as the producer countries are hit by periodic droughts (El Nino takes its toll), floods and devastating cyclones. Demand shifts are primarily caused as processors switch between competing oils and oil seeds. Further instability can be caused by changes in price support policies, in importing countries and by the advertising campaigns of competitors. ${ }^{8}$

Price instability in the vegetable oil market is transmitted verv directly to copra prices because 64 per cent of the weight (or 80 per cent of the value) of this 'oil seed' is in its oil. 34 per cent of the weight (the other 20 per cent of the value) is in the by-product of copra-cake -a livestock feed. These proportions contrast markedly with soybean where 18 per cent of the wight is in the oil and 80 per cent in the meal. Copra cake is currently in good demand in Eu rope as the processing is done there and it by-passes the restrictions on grain imports. Legislative action freeing up grain imports could eliminate this market overnight.

While farmers can be protected agairyst instability, as demonstrated by the very successful stabilization funds for coffee and copra in Papua new Guinea and copra in the Solomon Islands, balance of payments figures can "yo-yo". For example, in the Solomons, earnings from copra exports fluctuated from SI\$ 8.4 million in 1983, to $\$ 32$ million in 1984, to $\$ 23.5$ million in 1985 , and back to only \$6 million in 1986.

\footnotetext{
8 Thus, if the natural vagaries of the weather and standard international trade were not enough of a problem, two further trade threats have manil sted themselves recently: the American Soybean Association of the United States has mounted a major public campaign against "Tropical Oils" - supposedly on health grounds (see 'A New Kind of Oil Crisis' in AsiaWeek Sept 6, 198 7, pp. 55-57. And on the health issue, the US Congressional testimony HR. 2148, 10 Sept 1987). In Europe, a proposed tax on vegatable oils has again been mooted.
} 
However, there is even greater concern over the price trends. Over the whole period given, in Figure 1, the real prices show a decline of 1.44 per cent per annum or an average annual decline of about US\$ 11 per ton. ${ }^{9}$ The downward trend is halted in the World Bank projections with some recovery expected in the late 1980s from the low prices of 1985 and 1986. In fact, prices started to recover well in 1987 and are likely to be further boosted as the effects of drought and cyclones in the Philippines in 1986/7 deliver their delayed impact on world supplies. Globally, copra is a static industry with a steadily declining share of the world fats and oils market. It is little wonder that it has been described as a sunset industry. However, the trade figures underrate the overall significance of coconuts within the domestic econornies of individual countries. The per capita figures in Table 2 give a better indication of this. Fresh nuts are an important source of food. Vanuatu is an extreme example, where, apart from exports, per capita consumption is reported to be 15 nuts per household per day (for both humans 161 and livestock [9]) (APCC 1986, p. 234/5).

\subsubsection{Import trade}

There are two major concems with the effects of trade-dependency on the import side of the trade balance and on the islands' traditional position of relative self-reliance. First, there is the problem of the ability of the islands to continue to feed themselves in the face of a changing population distribution. This will be taken up later. Secondly, there is the issue of energy supplies. The Solomon Islands provide an example of the typical pattern of energy use in the South Pacific: two-thirds of the total final energy demand is met by indigenous biomass in the form of fuelwood. The rest comes from petroleum. The petroleum fuels are entirely imported and account for about twenty per cent of the value of imports. Consumption has increased by over nine per cent per annum during the 1980s (Jasiewicz, 1987). Diesel oil accounted for three quarters of these fuel imports in 1986. Electricity in the Solomon Islands is entirely diesel generated although the major demand for diesel is for marine operations and road transport. Typically in the islands electricity, where available, is expensive - ranging from about US\$.15 to 0.20 per kilowatt hour.

An energy import dependency ratio of one third might be considered to be quite acceptable, until it is recognised that this third is consumed entirely in the modern sector of the economy and that petroleum products make up one fifth of imports. Thus the manufacturing and transport sectors and the balance of payments are extremely vulnerable to any future increases in international oil prices (Complex System 1986).

\subsection{Aid dependency}

Foreign aid dependency. is also extreme among the South Pacific nations where thp, per capita receipts are among the highest in the world. Such massive aid dependency has much the same adverse 'Dutch disease' effectson economic development as a major mineral discovery, raising the exchange rate and making local industries less competitive in international trade (Cole and Parry 1986). This aid dependency, seriously distorts domestic factor markets, making agriculture a relatively unattractive place of employment (Fisk 1981 and 1986) while the remittances of migrants have the danger of further distorting the link between productive activity and consumption levels (Connell 1980).

\footnotetext{
9 The real prices are those obtained by deflating the current annual average prices by the Manufacturing Unit Value (MUV) index. For the equation $\mathrm{Y}=\mathrm{A}^{\mathrm{ert}+\mathrm{u}}$ where $\mathrm{Y}$ is the real price of copra deflated by the MUV index, $\mathrm{r}$ is the compound rate of growth, $\mathrm{t}$ is time (1953-85) and $\mathrm{u}$ the error term, the following results were obtained

$\begin{array}{cccc}\text { Parameter } & \text { Coefficient } & \text { T-ratio } & \\ \text { Ln A } & 6.5999 & 73.97 & \text { Corrected R2 }=0.2185 \\ \text { r } & -0.0144 & -3.15 & \end{array}$
}


A great many observers of the South Pacific have grappled with the complex issues involved in the economic development of the islands. There are certainly no obvious solutions (see Shand ed 1980; Ward and Proctor (ed) 1980; Fairbaim 1985; Brookfield, Ellis \& Ward 1985; Cole and Parry (ed) 1986). But, 'Unless and until these island states can get closer to economic self-reliance, they remain dependent on the goodwill of aid donors' (Arndt 1986). In some cases, amelioration of the situation is seen in the development of tourism, fisheries and forestry. However, for the agricultural sector some speak of the need of restructuring the mixed (subsistence and cash cropping) smallholder farms towards a plantation mode of management' (Ward et al. 1980). Smallholder peasant agriculture is explicitly ruled out as forming a viable basis for future development (Sevele 1980) - not least because of land tenure conflicts between aspiring individuals and traditional land networks. Nevertheless, the smallholders of the Pacific Islands have shown themselves as responsive to economic incentives since the Second World War (see, for example, Connell 1978, Bollard 1979, Stent 1984, Etherington \& Carrad 1985 and Fleming \& Hardaker 1986) as their counterparts in Asia did before WW I and Affica did between the World Wars (Myint 1964 chapter 3, Jones 1960). For example, within the coconut sector, Etherington and Carrad (1985, p. 88) note the achievement of smallholders in the Solomon Islands in producing 70 per cent of 30,000 tonnes of copra in 1980 as against only 10 per cent of 20,000 tons forty years earlier. If one excludes ten years for the impact of World War II and its after-math, the annual rate of increase in production has been over 7 per cent.

Is it possible to conceive of a feasible and realistic development strategy which makes better use of the coconut resource and provides a more rewarding return to the farmers than copra production? This is a key question. We now turn to consider some of the policy issues to be faced in developing such a strategy.

\section{MARKETS REVISITED}

\subsection{Domestic demand}

The growth of domestic demand shown in equation (1) can be decomposed into rural and urban components by recognising that the total growth rates (of population ' $\mathrm{p}$ ' and income ' $\mathrm{g}$ ') are the sums of the rural $(\mathrm{r})$ and urban $(\mathrm{u})$ growth rates weighted by the relative size of the sectors. This is done in equation (2):

$$
d=\left[P_{r}{ }^{P r}+p_{u}{ }^{P u}\right]+\left[n\left(g_{r} G r+g_{u} G u\right)\right]
$$

where the subscripts ' $r$ ' and $V$ refer to rural and urban and $P_{r}, P_{u}, G_{r}$, and $G_{u}$ refer to the proportions (in the totals) of rural and urban population and income respectively.

The farm populations of the Pacific islands are relatively well off by the standards of rural peoples gencrally, so the income elasticities of demand for food are likely to be low. Hence the income effects in equation (2) are likely to be very much less than the population effects. The high proportion of the population in the rural sector $\left(\mathrm{P}_{\mathrm{r}}\right)$ in these countries, implies that the growth of rural population will dominate medium term domestic demand for most countries. Few of these countries have large urban populations.

At the same time the growth rate of the domestic demand for purchased foods (in the urban sector) can be very high because of an initially small urban base, high rural/urban wage differentials and the high rates of urban population growth with the immigration from outer areas (and one might note, from tourism). In island economies this implies the need to develop the marketing and transport infrastructure. Otherwise, imported convenience foods will dominate urban (and tourist) markets and remove this potentially important source of rural cash incomes. Unfortunately, it is often very much cheaper to import food to the major towns of island nations than it is to grow it domestically and transport it within an island or between islands. Staples in particular are bulky and 
have low value so that inter-island shipments will be limited. Many are too perishable to stand slow and irregular shipping (see Dunbar 1982 for the case of Vanuatu). The standard marketing functions relating to form, place and time are exceedingly difficult to perform with the degree of consistency expected by urban dweIlers. 'Rice imperialism' tends to have absolute sway. Furthermore, as urban incomes, increase, supermarket-tastes further distance urban consumers from national farmers. ${ }^{10}$

Such weak actual and potential domestic linkages imply that the growth of the major urban markets (particularly the capital cities and significant deep-water ports) may not have the demand pull on the agricultural sector that is a feature of the traditional model of structural transformation. The 'missing links'in the production and marketing chain will require substantial investments. If such investments are not to worsen the high wage scenario painted by Fisk (1986), they will have to be linked to productive activities.

Equation (3) is a modification of equation (2) and shows the components of the rate of growth of the demand for purchases of any specific agricultural commodity (i) in an open economy (Johnston \& Kilby 1975 p.67).

$$
d^{i}=w_{1}\left(p_{u}+n^{i} g_{u}\right)-w_{2} m^{i}+w_{3} x^{i}
$$

Here the notation is the same as before but with the addition of the rate of growth of imports $(\mathrm{m})$ and exports (x) and weights ( $\mathrm{w} 1,2,3)$ for the relative importance of the three components. It is clear that if urban demand growth is small and/or is balanced by import growth then the only source of demand growth must be exports.

\subsection{Export markets}

Large open economies, such as Thailand with its rice and cassava exports, can 'afford' to direct their agricultural export trade towards large volumes of bulky commodities. However, small open economies need to look for low-volume, high unit-value export commodities aimed at selected market niches. Three corollaries follow :

First, the less developed the domestic infrastructure, the greater the need to foster the export of high unit-value commodities. In the islands of the South Pacific, export commodities must be able to bear the high costs of inter-island and trans-oceanic transport. In general, agricultural commodities meeting this requirement are luxuries' and will have a relatively higher FOB value added. (The export of vanilla by Tonga is a good example).

Second, the more one can economically 'concentrate', or process, a product so as to increase, the value per unit volume by either increasing the value (better quality) or reducing the volume, the better.

Finally, where imports are in a raw form, it is most likely that at the end of the trade route, that is, on the more remote islands, import substitution in the form of self-sufficiency is likely to pay thegreatestdividends. The use of domestic energy resources rather than imported fuel oil is a case in point.

\subsection{Research priorities}

Are these conclusions relevant within the South Pacific island environment? Of this environment it has been said that 'Cash cropping as an adjunct to subsistence farming within the

\footnotetext{
${ }^{10}$ For example, food (16\%) and beverages and tobaco (4\%) make up one fifth on Solomon Islands imports in 1986 (Central Bank S.I.1987, p.xviii).
} 
mixed subsisence-cash cropping mode largely precludes good management. If the participant is content merely to obtain a limited cash income, the system may be adequate. If, however, aspirations are high, productivity possibilities are limited by the scale of operation, even if sound technology is available .........The alternatives open are to specialize in fewer crops or seek increases in the size of the hold ings.' (Sumbak in Ward et al 1980, p.243).

One cannot help but wonder at how foreign experts would have advised the Japanese a century ago in regard to a suitable development strategy for their agriculture. I suggest that they would have been astonished to then leam that :

'One of the characteristics of the so called "Japanese Model" is that the bulk of the nation's farmers have been involved in increases in agricultural productivity associated with the use of improved varieties, fertilizers, implements and other complementary inputs within the almost unchanged organizational frame work of the existing small-scale farming system' (Ohkawa 1972, p.277). (My emphasis added).

It is recognised that harsh readjustment decisions for Japanese agriculture were avoided by cheap imports of staple products from subject states and by the later rapid industrialization which permitted heavy subsidies to agriculture. Nevertheless, it is important to ask whether it is possible to consider any strategies for development in the islands that leaves 'almost unchanged' smallholder farming systems that have been referred to as assentially 'terminal' (Epstein 1963, Howlett 1973, Howlett et al 1976, and Ward et al 1980). It is the contention of this paper that this could be possible for the coconut producers of the islands given a radical change in the strategic research priorities of the industry away from a production orientation toward processing and marketing.

In July 1984, the Second South Pacific Islands Regional Meeting'for research, development, extension and training in coconut was held in Vanuatu. The nine pages of recommendations have but one short paragraph devoted to processing and this refers to improved copra drying methods. Most other recommendations relate to various aspects of field production: improvement of varieties; agronomy (plant nutrition, intercropping, and replanting); and pests and diseases. Only under a minor sub-heading is there reference to the need to 'undertake research into the development and use of coconut by-products including feeds, fuel, timber and fencing material.' (Persley 1984, Annex E, p.7). In his discussion of research priorities on coconutsin the South Pacific, Raff (1984) concentrates entirely on issues relating to the various aspects of field production. A similar emphasis seems to be at the core of the FAO Asia/Pacific Coconut Project (Persley 1984, p.32). ${ }^{11}$

Such research recommendation imply development strategies led by supply shifts, that is, lowering existing farmers' costs of production. The frank question must be asked : are the improved planting materials and cultural practices that such research generates going to be adopted by smallholder farmers while current low prices persist? The answermustbe negative, given the evidence for economic rationality imphed in the positive response of farmers to price changes (Fleming \& Hardaker 1986). A 'supply-shift' development strategy is highly unlikely to resolve the dilemmas of the industry, much less those of the islands. But such recommendations raise the further question: how are increased incentives and profitability to be achieved for this vital sector of the island economies?

In terms of overall agricultural sector policy for the islands, Fleming et al (1 987, p.8) have correctly stressed the need for 'improvements in the marketing system'; Overcoming institutional impediments to development'; and 'Stimulating rural industries'. These 'key components' of a smallholder development strategy are seen as necessary complements to the 'Introduction of

${ }^{11}$ It may well be that such research priorities were guided by the very high copra prices of 1984, prices which the regional meeting anticipated would continue for about five. years (Raff 1984, p.2). 
improved production technologies'. This too is the implication of the same authors' earlier detailed discussion of the merits of three alternative agricultural development strategies. Mether these develop (a) around the existing village based semi-subsistence agriculture, or (b) around nucleus-estates or (c) with plantations, improved marketing is seen as essential (Hardaker et al 1986).

Fisk makes a similar plea :

within the rural sector itself, it is not sufficient to deal only with problems of farm management and agronomy, but the economic and social infrastructure, and all the factors that contribute to it 'Fisk (1 986, p. 19)

\section{A DEMAND PULL STRATEGY}

In keeping with these views this paper calls for a strategy for the coconut industry led by changes in processing and marketing. While not ignoring the importance of productivity changes at the farm level (see Etherington 1984), this strategy for both research and development is, primarily, a 'demand pull'. rather than a 'supply push' strategy. It is interesting to note that such a strategy is ruled out of current assessments of national and international agricultural research priorities because these explicitly assume static demand situations (Davis and Ryan 1987 p.9). Likewise, and almost by definition, Farming Systems Research, tends to ornit demand studies from its purview (see Remenyi 1985). And yet, as Sundquist (1984) points out in relation to the United States :

'Technology has also changed greatly in thosesegmentsof the farm and food systern which lie beyond the farm gate. Since World War II this "post harvest" or "processing and distribution" sector of the food system has grown steadily in importance.'

\subsection{Some theory}

In situations in which an agricultural commodity is processed into a new form or has improved marketing, such changes in technology represent a demand shift for the producer of the raw material. This is clearly laid out by Freebairn, Davis and Edwards (1 982) in their discussion of the research gains in multistage production systems. A slightly modified version of their diagram. is given in Figure 2.

Here, with the simplifying assumption of linear demand and supply curves, the diagram shows the comparative statics of the gains to farmers $\left(\mathrm{G}_{\mathrm{f}}\right)$ consurners $\left(\mathrm{G}_{\mathrm{c}}\right)$ and the aggregate gains (G) from that reduce 'marketing' ${ }^{12}$ costs or lower farm production costs. Retail or final consurner demand is $\mathrm{D}_{\mathrm{r}}$. The constant per unit cost of providing marketing services is $\mathrm{M}$. The derived demand for the farm product is $D_{\mathrm{f}}=\mathrm{D}_{\mathrm{r}}-\mathrm{M}$. The farm product supply curve is $\mathrm{S}_{\mathrm{f}}$. With these assumptions, the initial equilibrium position is where the quantity of output is $Q$, retail price is $P_{r}$ and the farm price is $\mathrm{P}_{\mathrm{f} .}$.

Consider a change in technology in the 'marketing' stage. This could involve a reduction in storage, transport, processing and/or distribution costs. Here the cost is re duced by V per unit. Thus the retail-farm margin falls from $\mathrm{M}$ to $\mathrm{M}^{\prime}$ leading to an upward shift of the farm product demand curve from $D_{f}=D_{r}-M$ to $D_{f}=D_{r^{-}} M^{\prime}$. The respective gains from this reduction in marke ting costs are:
(1) $\mathrm{Gc}=1 / 2\left(\mathrm{P}_{\mathrm{r}}-\mathrm{P}_{\mathrm{r}}^{\prime}\left(\mathrm{Q}+\mathrm{Q}^{\prime}\right)\right.$
[ shaded area /IIIII/ ]
(2) $\mathrm{Gf}=1 / 2\left(\mathrm{P}_{\mathrm{f}}^{\prime}-\mathrm{P}_{\mathrm{f}}\right)\left(\mathrm{Q}+\mathrm{Q}^{\prime}\right)$
[ shaded area IIIII ]

\footnotetext{
12 'Marketing' is placed in quotation marks because here it pools all transport, storage, processing and actual marketing/selling costs.
} 

(3) $G=1 / 2 w\left(Q+Q^{\prime}\right)$.
[ area SRDC ]

A number of conclusions follow from Freebairn et al's detailed algebraic manipulations, two of which are important to the present purpose. First, both consumers and farmers can gain from technological change. Secondly, the gain to farmers is greater than the gain to consumers if the slope of the demand curve is flatter than the slope of the farm supply curve. The authors prove this mathernatically in terms of demand and supply elasticities.

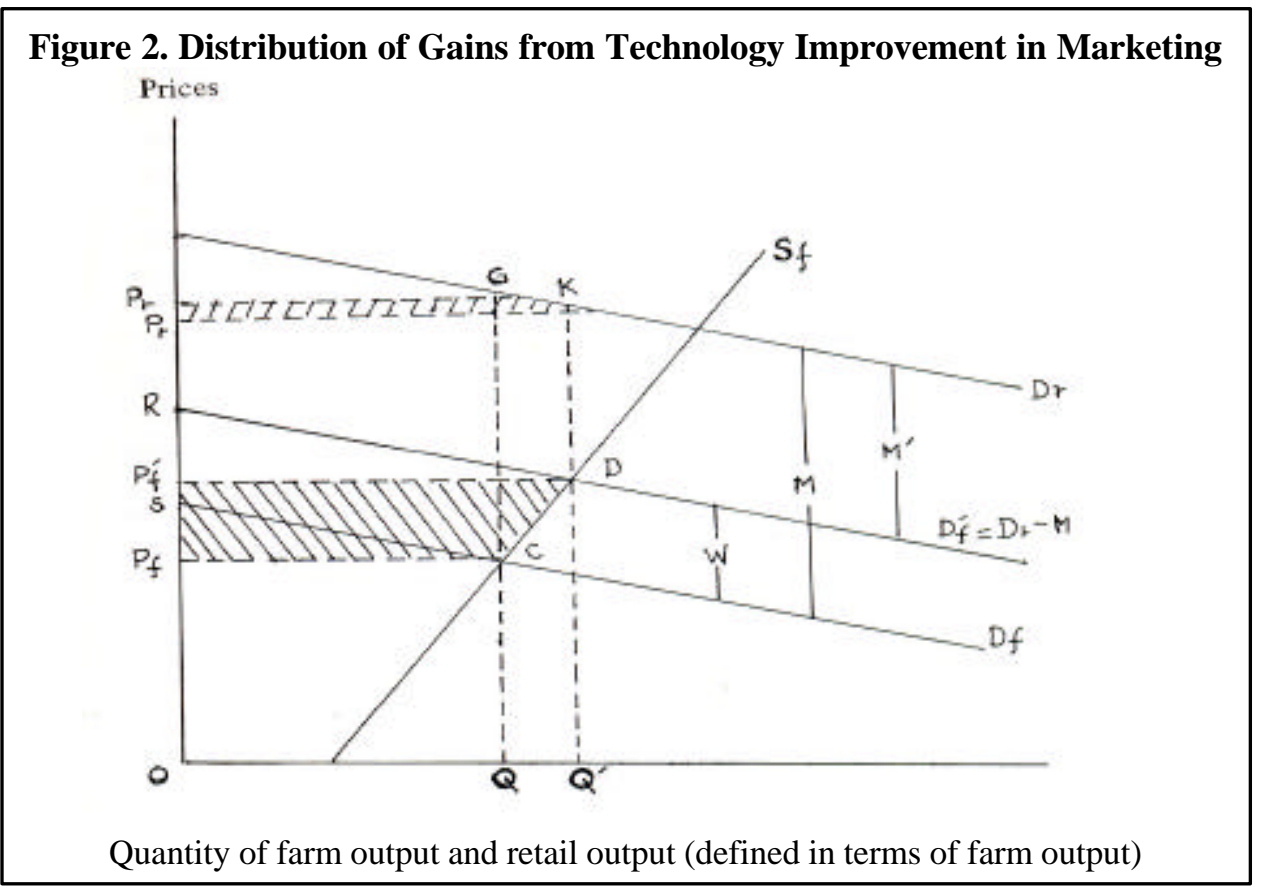

The second result is very important the coconut industry of the South Pacific because not only is each nation faced with a perfectly elastic demand curve, but the whole region, with well less than ten per cent of the market for coconut products (see Table 2), is faced with a flat demand curve. At the same time the short run supply elasticities of copra appear to be relatively inelastic (Fleming \& Hardaker 1986). In such circumstances most of the gains from technological. change, be it in marketing or in farm costs, can be to the farmers' benefit provided the changes do not simply spillover to all other coconut producing countries.

In addition to the reduction in 'marketing' costs, in the case of the coconut industry of the South Pacific, there is the real possibility of an upward shift in the market demand curve $\left(D_{r}\right)$ with the sale of quality coconut food products (coconut milk, cream, powder etc) and new commodities (for the islands) such as coir and activated carbon.

\section{$5.2 \quad$ Successful examptes}

\subsubsection{The Anand Milk Union}

The development of the cooperatives of the Indian National Dairy Development Board is a classic case of the success of such a 'demand pull' strategy. The Anand Milk Union initially in terfered minimally with traditional ownership paterns and live stock production systems but provided the requisite processing channels which later led to the demand by producers for improved management options. By 1977 the Union was collecting a peak (in winter) of 600,000 litres of milk a day through collection centres with a total membership of nearly 300,000 owning 
about 290,000 buffaloes and 37,000 cows. Here, based on the micro-producer owning only one or two milking animals, an infrastructure of collection points, processing plants and, later, veterinary services was developcd (Barnes 1980). A key feature was the more effective use of an existing resource base.

\subsubsection{Kenya smallholder tea}

The development of the smallholder tea industry in Kenya can be placed in a similar category. Although tea was a new cash crop for the farmers, it was introduced into the existing farming structure. Crucial to the success of the field activities of the farmers, was the development of a complementary infrastructure of extension, the provision of planting materials, and of transport, processing and marketing services (Etherington 1971, World Bank 1982). The rapid increase in smallholder tea production in Kenya was essentially the adjustment to 'disequilibrium caused by the removal of the technical, legal, financial, and administrative constraints that formerly prevented Africans frorn growing tea for the international market' (Etherington 1973). The market was opened to smallholders and the means to respond to that market were provided. The demand function for the excellent black tea produced by the smallholders in Kenya is a quantum leap from the sun-dried, home-made, tea typical of spontaneously grown smallholder tea in other countfies (Etherington 1974). ${ }^{13}$

It is not being argued from these two examples of the success of a demand pull strategy that such a strategy is capable of general application. Rather, that it is specifically relevant to the coconut industry of the South Pacific. This strategy requires that the coconut palm be viewed as a total resource rather than simply a source of copra. And, as in the Indian milk cooperative example, such a strategy is particularly attractive in making more efficient use of an existing and widespread, although diffuse, renewable resource. Thus, if effective, the strategy would have a marked impact on the overall economy of many of the island nations because coconut is both a traditional crop and also an important cash crop for many of them. Given the ubiquitous presence of the coconut palm in the lowlands of the islands, this approach will link in ideally with a village based strategy for the agricultural sector as a whole. This is particularly so if new processing facilities are of modest scale so that they are dispersed and not concentrated at one point in a country. Among the significantfeatures of the Kenya smallholder tea development is the location of the tea factories in rural areas. The linkage effects are substantial and essentially forced investment in rural roads and the associated infrastructure (see Stern 1972, Etherington 1971). This infrastructure is used for many purposes other than the transport of tea.

A 'demand pull' strategy for the coconut industry of the islands tums away from the defeatist agricultural development policies of so much of the writing on the Pacific and places the islands' agriculture at the leading edge of the total development process (see Mellor 1985 in a parallel context). Given sufficient incentives, farmers in the Pacific are likely to be willing to improve their cultural practices on the existing stock of coconut palms and possibly to use new planting materials when replanting or planting new areas. (The urgency for replanting large tracts of senile palms in the islands has often been stressed - see Fisk 1986 p.25 and Mason 1981 - but for a contrary view for the Solomon Islands see Etherington \& Carrad 1985).

The next substantive section of this paper looks at the key issues that need to be addressed in implementing a 'demand pull' strategy for the industry in the light of past experiences of coconut processmg in the South Pacific. On the surface, the past is not very encouraging.

\footnotetext{
${ }^{13}$ Schluter (1984) in exploring the extent to which Kenya's agricultural development strategy should explicitly seek out higher income market niches for its vegetables, flowers, beverages and animal products, was essentially examining the possibilities of a 'demand pull' strategy.
} 


\section{IMPLEMENTING THE STRATEGY}

\subsection{Past Attempts}

The World Bank regards agroprocessing industries as 'the first and most natural step towards industrialization' (World Development Report 1986, p.26) and the Asian Development Bank advised the Western Samoan Govemment that 'The processing of copra, the country's major agricultural cash crop and export commodity appeared a logical step'. These are the opening quotations in a paper by Wall (1 986) where he presents a convincing case that copra processing should not be taking place in the islands. One conclusion is that if the national govemments insist on doing so, the processing industry is likely to require continuing subsidies from the govemment exchequer. Wall surnmarises the general case as to why a country which exports a primary product may not be in a competitive location for processing that commodity :

'[The country] may not be a competitive producer of the product itself; it may not produce enough of the product to sustain processing; it may have factor endowments inconsistent with the factor requirements of processing; it may be non-competitive in the supply of other raw materials requireed; it may have insufficient skilled labour to undertake, manage and market the processing; it may not be able to export competitively due to transport or marketing costs; it may not be able to overcome the effect of cartels and monopsonies, etc; and, there may be domestic policies which thernselves li mit the prospects for competitively exporting the processed product.'(Wall 1986, p.1)

Wall uses such criteria in his analysis of the performance of the copra processing industries of Fiji and Western Samoa. He concludes that in both cases

'the industries are a net drain on national resources, making financial losses and giving a negative econornic internal rate of return... It also'needs to be recognise'd that both. Western Samoa and Fiji are relatively high wage econornies among coconut producers. The level of support prices needed to provide an adequate flow of nuts to the mills, given the expectation of continued lower world prices of [vegetable] oil, would require subsidies on a permanent basis. [Furthermore], Internal shipping costs required to collect the nuts from the many islands are another unavoidable cost raising factor in the Pacific .......

'In addition to having no competitive advantage in coconut production neither country has a competitive advantage in copra milling. This is primarily due to their transport cost disadvantages vis-a-vis their competitors in the main markets, and due to their lacking sufficient technical and managerial skills to run and maintain oil processing facilities on the basis of indigenous labour.' (Wall 1986 p.34-5). ${ }^{14}$

In the penultimate paragraph of his paper, Wall comes to the vital conclusion that

'In addition to the foreign exchange gained by exporting upprocessed copra, the domestic resources used in processing could be switched to support piivate sector based exportoriented production. Such opportunities exist both within the coconut sector (fresh nuts, coconut cream, activated carbon and timber) and for alternative agricultural products (Wall p.35-6, my emphasis)

\footnotetext{
${ }^{14}$ Rather than the blame residing with the technical and managerial skills of indigenous labour, this is testimony to the negative impact on these societies Of the permanent emigration of many islanders with precisely these skills. In Tonga a sad joke is voiced: the best and the worst Tongans live abroad, look for them in the executive offices and the prisons.
} 
Here, at the end of his study, Wall recognises that there may be more economic uses of coconuts than copra production - let alone processing the copra. The essential element missing in Wall's study is a failure to build on any recognition that the coconut palm, as such, is a valuable resource whose potential is grossly underrated if it only seen as a source of oil (or some other single use product, such as desiccated coconut). Copra production may have served the islands well in the past but it is technically and economically an extremely wasteful use of the total coconut resource. The losses and technical inefficiencies of copra production in the South Pacific include the almost complete waste of the husk and shell, and an extreme form of de-naturing a fresh food to produce a dirty and rancid product requiring complex chemical refining to obtain the pure bland oil required for food and industrial markets. It is hardly surprising that Jose Romero, the head of the Philippines Coconut Authority said that 'the copra process, the most primitive in the world belongs to the stone age. It involves aflatoxin contamination and reduces the value of end products for the producer who has to carry the additional costs brought about by free fatty acids, high moisture content [and heavy freight costs].' (Keynote address to the Asia and Pacific Coconut Community, July 1987). ${ }^{15}$

\subsection{The potential re-examined}

Figure 3 outlines some of the potential products and industries that can be developed from the coconut palm. ${ }^{16}$ In most of the islands, 'processing' is limited to those products above the dotted line. Strategic planning and research and development for the future of the coconut sector must keep the 'total resource' perspective of Figure 3 clearly in mind in any agenda for development.

The coconut palm is unusual among perennial fruit trees in the regularity of its production. Although the maturation of each bunch of nuts takes about four years, a new florescence is produced about every month (12 to 14 per year). Furthermore, the mature unhusked nut remains donnant for up to six weeks after it falls or is cut down (Child 1974). This dormancy is extended when nuts have been immersed in sea water. The nut is extremely well protected by the husk, it floats and can be handled roughly. Such regular production and excellent storage qualities in a raw material are important for the economics of food processing stockpiling requirements are minimised; and a customised plant can run at high capacity throughout the year. Furthermore, many of the coconut products can be produced jointly and are highly complementary with each other. To ignore such complementarities is to impose a heavy cost penalty on the industry.

The current wastage of biornass power resources illustrates the situation. Table 3 gives the average weight of the different components of Tongan coconuts delivered to the desiccated coconut factory. The standard energy conversion factors for a tonne of coconut husk (fibre and dust) and shell are 0.41 and 0.51 tonnes of oil equivalent (TOE) respectively. One hectare of mature palms should yield 6,000 to 20,000 nuts per year with a total weight of between about 8 and 27 tonnes giving between 3.3 and 11 tonnes of husk and about 1.2 to 4 tonnes of shell. This represents between about 2 and 6.5 TOE per hectare per year-Very little use is made of this energy in the islands-what shell is used is burnt for cooking and for drying some of the copra.

\footnotetext{
${ }^{15}$ In Australian terms, the parallel to the copra. trade would be if the annual offtake from the national flock of some 160 miHion sheep were all slaughtered on the farms and the meat sun-dried. This meat would be then exported in bulk to Europe, Japan and the United States where it would be cleaned, rehydrated, deboned, minced and canned as pet-food. Higher value uses (Cuts of the mutton/lamb) would be ignored and the wool and hides would be thrown away or burnt to assist the drying process.

${ }^{16}$ Woodroof (1979), lists more than 360 uses of coconut of which about 200 relate to food use.
} 


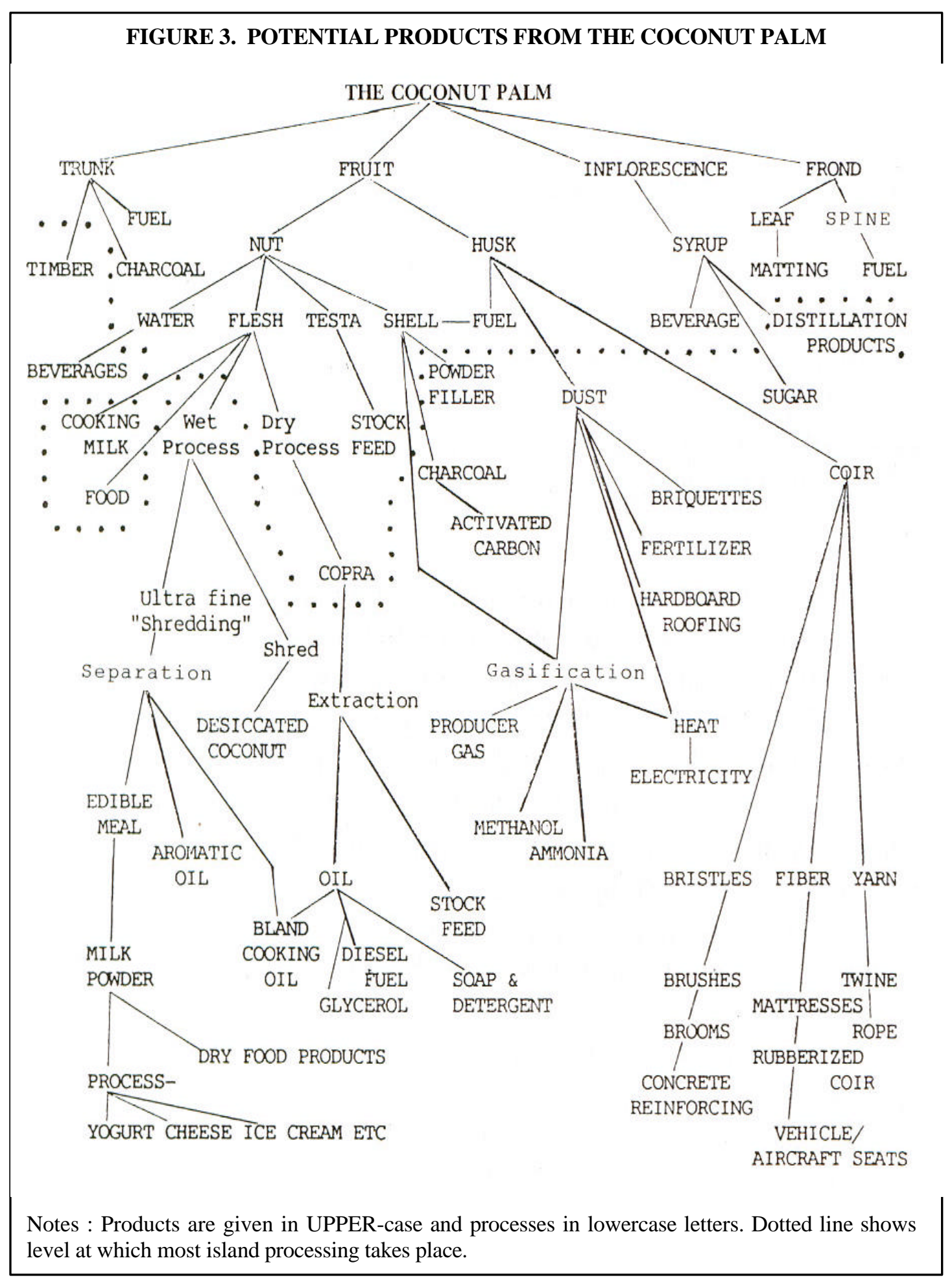


Table 3. The Weight of the Components of a Mature Fresh Coconut

\begin{tabular}{|l|c|c|c|c|c|}
\hline $\begin{array}{c}\text { Component } \\
\text { : }\end{array}$ & Husk* & Shell & Flesh** & Water & TOTAL \\
\hline Weight $(\mathrm{kg})$ & .55 & .2 & .4 & .18 & 1.33 \\
Per cent & 41 & 15 & 30 & 14 & 100 \\
\hline
\end{tabular}

* One third of the husk is fibre and two thirds is dust.

** The flesh (endocarp) is itself $50 \%$ moisture.

A specific example better illustrates the meaning of these numbers. Tonga has a modest copra milling plant which operated on a 24 hour schedule for 248 days in 1986. It processed nearly 8,000 tonnes of copra using 24 litres of diesel per hour plus electricity from the main grid (generated with imported diesel). This means that the total fuel used was about $345 \mathrm{TOE}$ (for a bill of over \$T 200,000 for the year or \$T 25 per tonne of copra processed). The energy available in the husks and shells of the nuts needed to produce 8 thousand tonnes of copra is 12,800 TOE. This difference is mind boggling. It represents the equivalent in energy terms of over 90,000 barrels of crude oil per year. And this from the discarded husks and shells of the nuts needed to produce only 8,000 tons of copra. ${ }^{17}$ Such resources can be used: Levers Solomons at the large plantations on the Russell Islands have reduced their costs of copra drying from $\$ 50$ to $\$ 10$ per tonne by switching from diesel to biomass driers. Brookfield reports on an estate in Fiji which installed a steam-heated copra drier which is linked to a steam-engine generator producing electricity as a by-product. The fuel used is primarily husk and shell (Brookfield in Brookfield et al 1985, p.204). Modern advances in cogeneration and reciprocating steam engines promise much greater fuel efficiency in the such situations (Kaneff et al 1987).

\section{CONCLUSIONS}

The policy perspective presented in this paper argues that the resource endowments of the island nations of the South Pacific require that research and development in the coconut industry be redirected from field agronomy and breeding towards improved processing and marketing. R \& D must concentrate on export products of high unit-value and on import substitution at the domestic end of trade routes. But such emphases must be within a total policy framework incorporates the coconut sector and the individual national economies as a whole. There are, major employment and balance of payments issues involved. Figure 3 shows a galaxy of opportunities. Initial fieldwork and reviews of the literature suggest that for the Islands the radical break must come with the processing of fresh mature nuts under some form of 'wet' or 'aqueous' processing (see Hagenmaier, 1980; Banzon et al 1982; UNIDO/IOD. 377 Vol IV and V) for food products of export quality. ${ }^{18}$ To exploit the full potential of such an approach the plant must be an integrated unit making concurrent use of the shell and the husk.

The technology alreacty exists for 'aqueous processing' for products such as virgin coconut oil, coconut cream, coconut 1 milk', spray dried powder and, indeed, desiccated coconut. Processing plants range in size from village level units handling 2,000 nuts per day in the Philippines (ATI 1987, Nuqui 1986) to massive operations in Brazil handling 220,000 nuts per day (SOCOCO, no

17 Such calculations when grossed up for the Philippines are indeed impressive and are even more startling when it is realised that the regularly falling petioles (fronds) represent more than as much energy again (Banzon \& Velasco, 1982, p.309).

${ }^{18}$ As Wall (1986) has shown, some of the more advanced island nations have had difficulty in processing copra for crude coconut ofl. The Islands certainly do not have the resource base to follow countries such as the Phihppines along the route of sophisticated further processing of copra for 'cocochemicals'. 
date). Many technologies exist for handling husks and shells for fuel and/or other purposes (see UNIDO 1980, Jarman et al 1986,Breag et al 1984). Integrated processing poses many questions for the islands: What are the appropriate products for the islands to produce and for which markets? What is the appropriate size of processing unit? Could units be designed to be located in provincial growth centres so as to provide local skilled employment and cheap power for other rural processing industries? Would the economies of scale in producing many smaller plants (using a centralised maintenance crew) result in greater benefits and lower costs of production than a large, one-off, centralised plant? Would a combination of plants be possible, with a set of small regional plants producing products suited to further centralised processing (for example, charcoal and activated carbon)? Mich way do the modern developments in membrane technology (Jones 1987; del Rosario et al 1986), in cogeneration, in improved gasifiers (Foley et al 1983), in microprocessors, in containerization (Brookfield 1984) and in ocean-going catamarans tip the balance? These and many other questions need answering. Out of the literature review and knowledge of the resource base of the islands specific technical problems need to be identified and become the subject of detailed research.

This paper has not sought to answer these questions but rather to set the stage and pose a challenge for a radical reconsideration of research priorities for the coconut industries of the South Pacific. Australia is probably better placed than any other aid donor country to meet this challenge and undertake such research. 


\section{REFERENCES}

APCC (1986). Coconut Statistical Yearbook 1985. Jakarta, Asian and Pacific Coconut Community.

ATI (1987). Willage coconut processing in the Philippines'. Appropriate Technology International, Washington. Bulletin No. 10, May/June.

ARNDT, H. W. (1986). Book Review Of COLE \& PARRY (1986) in Pacific Economic Bulletin 1: 1. July, p 19.

BANZON, J. A. \& VELASCO, J. R. (1982). Coconut Production and Utilization. Manila, Philippine Coconut Research and Development Foundation, Inc. pp.xxii + 351 .

BARNES, S. (1980). 200 Million Hungry Children, London, Grosvenor Books.

BENNETT, M. K. (1954). The World's.Food New York.

BOLLARD, A. (1979). Agricultural project design and evaluation in an island community. Monograph 15. ANU, Canberra, Development Studies Centre.

BREAG, G. R., HARKER, A. P., PADDON, A. R. \& ROBINSON, A. P. (1984). 'The design, construction and operation. of a unit for the carbonisation of coconut shell with recovery of waste heat.' Report of the Tropical Development and Research Institute, G 182, iv + 18pp. London. April.

BROOKFIELD, H.C. (1984). '4 Boxes, Ports, and Places without Ports' in HOYLE \& HILLING pp.61-79

BROOKFIELD, H. C., ELLIS, F. \& WARD, R. G. (1985). Land, Cane and Coconuts: Papers on the rural economy of Fift, Canberra, The Australian National University.

CENTRAL BANK OF THE SOLOMON ISLANDS (1987). Annual Report 1986. Honiara, Solornon Islands.

CHAMBERS, R. (1978). Towards rural futures: An approach through the planning of technologies'. Discussion Paper 134, Institute of Development Studies, University of Sussex, Brighton.

CHILD, R. (1974). Coconuts Second Edition. London, Longmans.

CHENERY, H.B. (1960). 'Tatterns of industrial growth.'American Economic Review. Vol 50 (Sept): 624-54.

COLE, R. V. and PARRY, T. G. (eds) (1986). Selected Issues in Pacific Island Development. National Centre for Development Studies, Australian National University, Canberra pp. vii + 264.

CONNELL, J. (1978). Taim bilong mani : the evolution of agriculture in a Solomon Island society. Monograph 12. ANU, Canberra, Development Studies Centre.

CONNELL, J. (1980). 'Remittances \& rural development: migration, dependency \& inequality in the South Pacific.' Occasional Paper No. 22. ANU, Canberra, Development Studies Centre. 
CONNELL, J. (1983). Migration, Employment \& Development in South Pacific. Various country studies. Noumea, South Pacific Commission.

CONWAY, G. R. (1985). 'Agricultural ecology and farming systems research.' in REMENYI (ED) (1985)

DAVIS, J. S., and RYAN, J. G. (1 987). 'Priority assessment in agricultural research: International and national perspectives.' Contributed paper. Australian Agricultural Economics Society Conference, Adelaide, February. 37p.

DAVIS, J. S. ORAM, P. A. and RYAN, J. G. (1987). Assessment of Agricultural Research Priorities: An International Perspective. Monograph No 4 Australian Centre for International Agricultural Research, Canberra, Australia.

del ROSARIO, E. J., PAPA, G. M., BERGONIA. H. A. \& REYES, C. S. (1986). 'Concentration of coconut water by plate-and frame reverse osmosis using cellulose acetate membranes.' ASEAN Food Journal Vol 2 No. 1 March.

DUNBAR, A. C. (1982). 'Control \& ownership of transport resources: interisland shipping in Vanuatu'. Ph.D. Thesis, The Australian National University.

EPSTEIN, A. L. (1963). The economy of modem Matupit: continuity and change in the Gazelle Peninsula, New Britain. 'Oceania, 33:182-2-15.

ETHERINGTON, D. M. (1971). 'Economies of scale and technical efficiency: A case study in tea production'. Kampala, East Affican J. of Rural Development. 4:1 p72-87.

ETHERINGTON, D.M. (1 973).An Econometric Analysis ofSmallholder Tea in Kenya. Nairobi, East African Literature Bureau.

ETHERINGTON, D. M. (1974). The Indonesian Tea Industry.' Canberra, Bulletin of Indonesian Economic Studies. 10:2 p83 -113.

ETHERINGTON, D. M. (1984). The design and economic evaluation of agroforestry technologies for the South Pacific.' Chapter VII in Schirmer, A, (Ed.) The Role of Agroforestry in the Pacific. (DSE, DOC 1233). p.71-88.

ETHERINGTON, D. M. \& CARRAD, B. (1985). 'Production policies for tree crops in the South Pacific: Conflicts of interest and perception in Papua New Guinea and the Solomon Islands.' Tree Crops - 84: Growing Up. Proceedings of the Second Australasian Conference on Tree and Nut Crops. Springvale, Victoria, Natural Resources Conservation League of Victoria. p.87-101.

FAIRBAIRN, T. I. J. (1985). Island Economies: Studies from the South Pacific. Suva: Institute of Pacific Studies.

FISK, E. K. (1962) 'Planning in a primitive economy: specialproblems of Papua New Guinea.'Economic Record, 38:462-478

FISK, E. K. (1962) 'Planning in a primitive economy: from pure subsistence to production of a market surplus.' Economic Record, 40:156-174 
FISK, E. K. (1971) 'Labour absorbtion capacity of subsistence agriculture.' Economic Record, 47:366-378

FISK, E. K. (1981) 'Aid in the South Pacific: too much or not enough?.' Seminar paper. ANU, Economics Dept. R.S. Pac.S. 17/3/81 24p

FISK, E. K. (1986) 'Facific Island Agriculture'. Islands/Australia Working Paper No. 86/8. 28p. ANU, Canberra, National Centre for Development Studies.

FLEMING, E. M. and HARDAKER, J. B. (1986). 'Agricultural supply response in the South Pacific region.' Islands/Australia Working Paper No. 86/16 ANU, Canberra, National Centre for Development Studies. 39p.

FLEMING, E. M., HARDAKER, J. B. and JONES, S. C. (1987). 'Agrarian Development Strategies of South facifle Island Countries. ' Paper Presented at the Australian Agricultural Economics Conference, Adelaide, February.

FOLEY, G., BARNARD, G., \& TIMBERLAKE, L. (1983). Biomass Gasification for Developing Countries. International Institute for Environment and Development, London.

FREEBAIRN, J. X, DAVIS, J. S. and EDWARDS, G. W. (1982). 'Distribution of Research Gains in multistage production systems.'Am J. Ag Econ 64:1. February p39-46.

HAGENMAIER, R.D. (1980). Coconut Aqueous Processing, Cebu City. San Carlos Publications. pp. $\mathrm{xi}+213$.

HARDAKER, J. B., FLEMING, E. M. and DELFORCE, J. C. (1986). 'Prospects for srmllholder development in the South facific: Background to research project.' Occasional Paper No. 1, South Pacific Smallholder Project, University of New England.

HARDAKER, J. B. and FLEMING, E. M. (1986a). The South facific smallholder project: Outline.' Occasional Paper No. 2, South Pacific Smallholder Project, University of New England.

HARDAKER, J. B. and FLEMING, E. M. (1986b). 'Policy issues in agricultural market development in the South Pacific region.' Islands/Australia Working Paper No. 86/17. 49p. ANU, Canberra, National Centre for Development Studies,

HOWLETT, D. (1973). Terminal development: from triballsm to peasantry.' in BROOKFIELD, $\mathrm{H}$. (Ed.). The Pacific in Transition. Geographical Perspectives on Adaptation and Change. New York: St Martin's P.

HOWLETT, D., HIDE, R., \& YOUNG,E. (1976). Chimbu: Issues in Development. Canberra, Development Studies Centre Monograph No. 4, A.N.U.

HOYLE, B.S. \& HILLING, D. (eds) (1984). Seaport systems and spatial change. London, John Mey $\&$ Sons, Ltd.

JASIEWICZ,. J. (1987). 'Energy conservation issues in Solomon Islands.' Restricted report for United Nations Economic Commission for Asia and the Pacific. Honiara, solomon Islands. April. 
JARMAN, C. G., \& ROPPINS, SAT (1986). 'An industrial profile of coconut fibre extraction and processing.' Report of the Tropical Development and Research Institute. G189, viii + 104pg. London. Oct.

JOHNSON, D. G. (1987). 'World agriculture in disarray revisited.' Plenary paper presented to the Australian Agricultural Economics Society Conference, Adelaide, February.

JOHNSTON, B. and KILBY, P. (1975). Agriculture and Structural Transformation: Economic Strategies in late-developing countries. London, Oxford University Press.

JOHNSTON, B. and MELLOR, J. W. (1960). The nature of agriculture's contribution to economic development.' Food Research Institute Studies $1: 3$

JONES, A. T (1987). Membrane and Separation Technology: The Australian Perspective. Canberra, Department of Industry, Technology and Commerce. January.

JONES, W. O. (1960). 'Economic Man in Africa'. Food Research Institute Studies, Vol 1, No. 2, May.

KANEFF, S., INALL, E. K. \& WEELAN, R. E. (1987). A range of high performance inflow reciprocating steam engines powered by solar, biomass and other sources of Steam.'Paper presented to the ISES Conference, Hamburg, September.

KUZNETS, S. (1957) Quantitative aspects of the economic growth of nations: II. Industrial distribution of national product and labor force.' Economic Development and Cultural Change. Vol 5 (July) Sup.

LONGWORTH, J. W. (1987) 'Biotechnology - Scientific potential and socioeconomic implications for agriculture. 'A paper presented to the Australian Agricultural Economics Conference, University of Adelaide, February 1987.

LUCAS, D. \& McMURRAY, C. (1986). 'Pacific Population Trends' Islands/Australia Working Paper No. 86/6. ANU, Canberra, National Centre for De velopment Studies

MASON, E. S. (1981). The coconut industry: present position and future policy.'in the Proceedings of the Solomon Islands Coconut Industry Workshop, Vol 2. Tambea. December.

MELLOR, J. W. (1985). The role of government and new agricultural technologies.' Food Policy Statement No. 4. Washington: IFPRI. November.

MOLL, H. A. J. (1987). The Economics of Oil Palm. Pudoc,.Wagenigen

MYINT, H. (1964). The Economics of the Developing Countries. Chap 3 London, Hutchinson \& Co.

NOQUI, H. (1986). 'A proposal for an integrated coconut processing plant.' a paper written for the Asian Institute of Management, Manila.

OHKAWA, K. (1972). 'Agricultural technology and agrarian structure.' Reprinted in MEIER, G. (Ed.) (1976). Leading Issues in Economic Development Third Edition. New York

Oxford University Press. pp.601-607. 
PERSLEY, G. J. (1984). 'Report on Sou th facific Regional Coconut Meeting'. Canberra, Australian Centre for International Agricultural Research. Unpublished.

RAFF, J. W. (1984). 'Research PKorities on Coconuts in the South Paciflc.' Canberra, Australian Centre for International Agricultural Research. Unpublished.

REMENYI, J. V. (Ed) (1985). Agricultural systems research for developing countries: proceedings of an international workshop held at Hawkesbury Agricultural College, Richmond, N.S.W. $12-15^{\text {th }}$ May.' Australian Centre for International Agricultural Research, Proceedings No. 1 $1,189 \mathrm{p}$.

SCHLUTER, M. (1984). Constraints on Kenya's Food and Beverage Exports. Research Report No. 44. Washington, International Food Policy Research Institute, 11 p.

SEVELE, F. (1980). 'How successful is smallholding farming in the South Pacific Islands.' Nournea, South Pacific Bulletin. 1 st Quarter.

SHAND, R. T. (Ed.) (1980). The island states of the Pacific and Indian Oceans: an anatomy of development. Monograph No. 23 ANU, Canberra, Development Studies Centre.

SOCOCO (no date). Product brochure for Sococo S.A. Industries Alimenticias, Alagoas State, Brazil.

STENT, W. R. (1984) TheDevelopmentofaMarketEconomyin the Abelam Monograph 20. Boroko, Papua New Guinea, Institute of Applied Social and Econornic Research.

STERN, N. H. (1972). An appraisal of tea production on smallholdings in Kenya. Paris, Development Centre of the OECD.

STEWART, F. \& STREETEN, P. (1976). 'New strategies for development: Poverty income distribution, and growth.'Oxford Economic Papers. 28

SUNDQUIST, W. B. (1 984). Technology and Productivity Policies for the Future.' Pamphlet No 4 of a series on 'The Farm and Food System in Transition : Ernerging Policy Issues.' Published by the Cooperative Extension Service, Michigan State University, Michigan.

UNIDO (1980). Coconut Processing Technology Documents. Seven volurnes. UNIDO/IOD. 377.

WALL, D. (1986). 'Coconut processing in the Pacific Islands.' Islands/Australia Working Paper No. 86/18. ANU, Canberra, National Centre for Development Studies.

WARD, G. R. \& PROCTOR, A. (ed.) (1980). South Pacific Agriculture: Choices and constraints. South Pacific Agricultural Survey, Canberra, ANU Press.

WORLD BANK (1982). Control, Accountability, and Incentives in a successful development institution: The Kenya Tea Development Authority. Staff Working Paper No. 550. Washington.

WORLD BANK (1986). Price ftospects for Major Primary Commodities. Report No. 814/86. Vol II: Food products and fertilizers. Washington. October. 